\title{
Characterization of constituents, quality and stability of pomegranate seed oil (Punica granatum L.)
}

\author{
Illana Louise Pereira de MELO ${ }^{1}$, Eliane Bonifácio Teixeira de CARVALHO ${ }^{1}$, Ana Mara de Oliveira e SILVA², \\ Luciana Tedesco YOSHIME ${ }^{1}$, José Augusto Gasparotto SATTLER ${ }^{1}$, Rosângela Torres PAVAN ${ }^{1}$, Jorge MANCINI-FILHO ${ }^{1 *}$
}

\begin{abstract}
This study aimed to characterize pomegranate seed oil and evaluate its quality and stability parameters against those of linseed oil. The profile of fatty acids and phytosterols and the content of tocopherols were analyzed by gas chromatography and high performance liquid chromatography, respectively. The quality of both oils was assessed as recommended by the American Oil Chemists' Society (AOCS) and stability was evaluated using 2,2-diphenyl-1-picrylhydrazyl (DPPH), $\beta$-carotene bleaching (coupled oxidation of $\beta$-carotene/linoleic acid) and Rancimat ${ }^{\circledR}$ assays. While $\alpha$-linolenic acid (52\%) was the most abundant fatty acid in linseed oil (LO), punicic acid (55\%) was highest in pomegranate seed oil (PSO). Tocopherols and phytosterols ( 175 and $539 \mathrm{mg} / 100 \mathrm{~g}$, respectively) were greater in PSO than in LO (51 and $328 \mathrm{mg} / 100 \mathrm{~g}$, respectively). Both oils met quality standards. The $\beta$-carotene bleaching and the DPPH assays showed greater oxidative stability for PSO than for LO. The Rancimat ${ }^{\circledR}$ method, on the other hand, indicated low stability for both oils.
\end{abstract}

Keywords: punicic acid; tocopherols; phytosterols; coupled oxidation of $\beta$-carotene; DPPH•.

Practical Application: Pomegranate seed oil: compostion, quality and stability.

\section{Introduction}

Evidence shows that not only the amount of fat consumed, but also the type of fat, particularly certain fatty acids (Trans, CLAs, CLnAs), are important factors both in maintaining health and in developing certain diseases (Zock, 2006). Consequently, the role of oils and fats in the human body has been widely researched in recent decades and studies have led to a deeper knowledge of their composition and chemical structure as well as their better characterization (Mancini-Filho et al., 2007). Characterizing each class of food lipids is an essential step in developing tailored applications in the food and health industries. In the light of this, the lipid profile of numerous fruits and their seeds have been characterized and several bioactive compounds have been isolated (Pande \& Akoh, 2009).

The pomegranate seed oil (PSO) has attracted increasing interest thanks to the abundance of punicic acid (PA - C18:3 - $9 c$, $11 t, 13 c)$, a positional and geometric isomer of $\alpha$-linolenic acid (LNA, C18:3-9c,12c,15c). Its structure with two cis double bonds and one trans double bond has been investigated in order to understand its role in physiological processes. According Elfalleh et al. (2011), the potent antioxidant, anticarcinogenic and antilipidemic properties of PSO makes it a powerful health-promoting agent.

The separation and identification of CFAs (conjugated fatty acids) have gained momentum as numerous studies have proven their in vitro and in vivo biological activities (De la Fuente et al., 2006). In analyzing CFAs, it is essential that the method chosen be capable of separating and quantifying these geometric and positional isomers, avoiding additional isomerization during any stage of derivatization (Christie et al., 2007). The identity characteristics of vegetable oils include their fatty acid composition as well as their levels of phytosterols (Mancini-Filho et al., 2007). Phytosterols belong to a class of health-beneficial compounds especially known for their ability to inhibit cholesterol absorption. Tocopherols act as natural preservatives and their presence in seed oils is often correlated with the relative abundance of unsaturated fatty acids (Caligiani et al., 2010).

Some researchers have attributed the health-beneficial effects of CFAs to their antioxidant properties (Ali et al., 2012; Johanningsmeier \& Harris, 2011; Tsuzuki et al., 2004; Yu, 2001). However, their in vitro antioxidant activity has been investigated in few studies. Elfalleh et al. (2011) advocates that the liposoluble nature of fatty acid conjugates limits the choice of assays for estimating their antioxidant capacity; its assessment has been confined to the DPPH • radical (2,2-diphenyl-1-picrylhydrazyl) test, which can successfully determine the antioxidant capacity of the isomers of the conjugated linoleic acid (CLAs). The same researchers have suggested that the high scavenging activity of CLAs against DPPH• free radicals may contribute to their biological activity. This observation is in agreement with findings by Fagali \& Catalá (2008), who also demonstrated the ability of isomers of CLAs to reduce free radicals using a photoemission test (lipid peroxidation of PUFAs was induced by tert-butyl hydroperoxide (TBH) and the reduction in chemiluminescence, 
brought about by adding isomers of CLAs, was monitored) and a spectrophotometric assay (the decrease in absorbance of a solution containing the DPPH• radical through the addition of the isomers of CLAs was monitored).

Studies on isomers of conjugated $\alpha$-linolenic acid (CLnAs), such as punicic acid (PA), are, on the other hand, still rare - little is known about the identity, quality and stability of oils containing CLnAs. Pomegranate seed oil (PSO), rich in PA and a promising dietary component with potential health-promoting properties, remains poorly characterized. Therefore, this work aimed to characterize PSO in terms of its profile of fatty acids, tocopherols and phytosterols and evaluate its quality and stability parameters against those of linseed oil (LO), which contains $\alpha$-linolenic acid as the major fatty acid.

\section{Material and methods}

\subsection{Material}

The pomegranate seed oil (PSO) was directly imported from Green Source Organics (Boynton Beach, USA). The oil, consisting mainly of punicic acid (PA, C18:3 - 9c, 11t, 13c), an isomer of conjugated $\alpha$-linolenic acid, was obtained by the cold pressing of the seeds of pomegranate. Samples of linseed oil (LO), provided by Vital Âtman (Uchôa, Brazil) and also obtained by cold pressing, were used for comparison because a-linolenic acid (LNA, C18:3 - 9c, 12c, 15c) is its major fatty acid as well.

\subsection{Methods}

\section{Fatty acids profile in $L O$ and PSO}

Identification and quantification of fatty acids were performed by gas chromatography using different methodologies.

Two esterification methods were used to prepare methyl esters of fatty acids for chromatographic analysis: an acid/base-catalysed method and a base-calalysed $\left(\mathrm{NaOCH}_{3}\right)$ method, as described by Christie et al. (2001). Briefly, the lipid fraction (50 mg of oil), containing fatty acids, was diluted in $1 \mathrm{~mL}$ of toluene and $2 \mathrm{~mL}$ of sodium methoxide $\left(\mathrm{NaOCH}_{3}\right)$ in methanol $(0.5 \mathrm{M})$ was added. The suspension was then heated to $50^{\circ} \mathrm{C}$ for 10 minutes. In the acid/base-catalysed method, $3 \mathrm{~mL}$ of boron trifluoride $\left(\mathrm{BF}_{3}-14 \%\right)$ was added and the suspension was heated once again in water bath $\left(50^{\circ} \mathrm{C}\right.$ for 10 minutes). Next, the tubes were cooled in water and glacial acetic acid $(100 \mu \mathrm{L})$, distilled water $(5 \mathrm{~mL})$ and hexane $(5 \mathrm{~mL})$ were added; the mixture was stirred by vortex mixing and the upper phase was collected and filtered through anhydrous sodium sulfate $\left(\mathrm{Na}_{2} \mathrm{SO}_{4}\right)$. The lower phase was washed again with $5 \mathrm{~mL}$ of hexane and the upper phase was collected. It was then evaporated under $\mathrm{N}_{2}$, resuspended in $2 \mathrm{~mL}$ of hexane and injected into the chromatograph.

Gas chromatography (GC) analyses were carried out in a Shimadzu GC-2010 chromatograph equipped with a flame ionization detector. Samples were run on a fused silica capillary column (SP-2560, $100 \mathrm{~m} \times 0.25 \mathrm{~mm}, 0.2 \mathrm{~mm}$ film) under three different chromatographic conditions (CC): (1) Injector and detector temperatures were $250^{\circ} \mathrm{C}$ and $275^{\circ} \mathrm{C}$, respectively. The temperature gradient was as follows: $70^{\circ} \mathrm{C}$ for $4 \mathrm{~min}, 70-175^{\circ} \mathrm{C}$ at $13^{\circ} \mathrm{C} / \mathrm{min}$, $175^{\circ} \mathrm{C}$ for $27 \mathrm{~min}, 175-215^{\circ} \mathrm{C}$ at $4^{\circ} \mathrm{C} / \mathrm{min}$ and $215^{\circ} \mathrm{C}$ for $31 \mathrm{~min}$ (Kramer et al., 1997); (2) Injector and detector temperatures were $215^{\circ} \mathrm{C}$ and $250^{\circ} \mathrm{C}$, respectively. The temperature gradient was as follows: $100^{\circ} \mathrm{C}$ for $4 \mathrm{~min}, 100-175^{\circ} \mathrm{C}$ at $10^{\circ} \mathrm{C} / \mathrm{min}, 175^{\circ} \mathrm{C}$ for $30 \mathrm{~min}, 175-220^{\circ} \mathrm{C}$ at $5^{\circ} \mathrm{C} / \mathrm{min}$ and $220^{\circ} \mathrm{C}$ for $15.9 \mathrm{~min}$ (Cordain et al., 2002); (3) Both injector and detector temperatures were $250^{\circ} \mathrm{C}$. The temperature gradient was as follows: $162^{\circ} \mathrm{C}$ for $32 \mathrm{~min}, 162-195^{\circ} \mathrm{C}$ at $1.4^{\circ} \mathrm{C} / \mathrm{min}, 195^{\circ} \mathrm{C}$ for $15 \mathrm{~min}, 195-235^{\circ} \mathrm{C}$ at $2^{\circ} \mathrm{C} / \mathrm{min}$ and $235^{\circ} \mathrm{C}$ for $5 \mathrm{~min}$ (Baublits et al., 2007).

Under the three different conditions, helium $(1 \mathrm{~mL} / \mathrm{min})$ was used as the carrier gas and the split ratio (the amount of sample entering the column) was 1:50. Fatty acids in the samples were identified by comparing their retention times with those for commercial standards (C4-C24 methyl esters - Sigma 18919) and the punicic acid with those reported in the literature.

\section{Content of tocopherols and phytosterols in LO and PSO}

The identification and quantification of tocopherols present in both oils were performed using high performance liquid chromatography (HPLC) and the content of phytosterols was determined by gas chromatography as described below.

The analysis of tocopherols was performed as recommended by Instituto Adolfo Lutz (2005). Samples were prepared as follows: an aliquot of oil was diluted in hexane, filtered through a $0.22 \mu \mathrm{M}$ membrane and injected into the chromatograph. A Shimadzu HPLC system, consisting of an autosampler and a fluorescence detector (RF-10AXL) (excitation: $295 \mathrm{~nm}$, emission: $330 \mathrm{~nm}$ ), was used. Samples were run under isocratic conditions on a Shim-pack CLC-Sil column $(25 \mathrm{~cm})$ at a flow rate of $1.0 \mathrm{~mL} / \mathrm{min}$ with a pre-filtered and degassed mobile phase of hexane and isopropyl alcohol (99:1). The identification of $\alpha$-tocopherol was based on retention time of synthetic standard ( $\alpha$-tocopherol Sigma T3251) and quantification was performed by external standardization. The other tocopherols were identified by comparison with literature data and quantified as equivalents of a-tocopherol.

Determination of phytosterols was carried out in three steps, as recommended by Almeida (2009): (1) hot saponification using $3 \% \mathrm{KOH}$ in water bath at $50^{\circ} \mathrm{C}$ under stirring for three hours; (2) extraction of the unsaponifiable fraction in hexane $(10 \mathrm{~mL})$ under vortex mixing for one minute and (3) quantification of phytosterols by gas chromatography. The system consisted of a Shimadzu GC-2010 chromatograph equipped with a DB-5 poly (methylphenyil) siloxane column (5\% phenyl, $60 \mathrm{~m}, 0.25 \mathrm{~mm}$ ) and a flame ionization detector. The temperature gradient was as follows: $150^{\circ} \mathrm{C}$ for $0.1 \mathrm{~min}, 150-300^{\circ} \mathrm{C}$ at $10^{\circ} \mathrm{C} / \mathrm{min}$ and $300^{\circ} \mathrm{C}$ for $10 \mathrm{~min}$. The temperatures of the injector and detector were $250^{\circ} \mathrm{C}$ and $300^{\circ} \mathrm{C}$, respectively. Helium $(1 \mathrm{~mL} / \mathrm{min})$ was used as the carrier gas and the split ratio (the amount of sample entering the column) was 1:50. Identification of the peaks was performed by comparing retention times with those of Sigma standards (campesterol - C5157, stigmasterol - S6126 and $\beta$-sitosterol - S9889) and quantification was done by internal standardization using $5 \alpha$-cholestane (Sigma C8003) as an internal standard. 


\section{Quality parameters of LO and PSO}

The quality parameters of both oils, Acidity Index (AI), Peroxide Index (PI), $p$-anisidine Index ( $p \mathrm{I})$ and 2-thiobarbituric acid (TBA) value, were evaluated by methods described in Mancini-Filho, et al. (2007), Instituto Adolfo Lutz (2005) and American Oil Chemists' Society (2004).

\section{Oxidative stability of $L O$ and PSO}

The oxidative stability of both oils was assessed using three assays:

(1) $\beta$-carotene bleaching (coupled oxidation of $\beta$-carotene/ linoleic acid) assay - Basically, the method described in Schubert et al. (1999) monitors the oxidation (discoloration) of a $\beta$-carotene emulsion with a spectrophotometer. Briefly, $0.2 \mathrm{~mL}$ of $\beta$-carotene/chloroform $(10 \mathrm{mg} / 10 \mathrm{~mL})$ solution, $20 \mu \mathrm{L}$ of linoleic acid and $0.5 \mathrm{~mL}$ of Tween-40 (emulsifier) was mixed for homogenization and the chloroform was then evaporated under $\mathrm{N}_{2}$. Subsequently, $50 \mathrm{~mL}$ of distilled water was added and the mixture was vigorously shaken to produce a clear $\beta$-carotene/linoleic acid emulsion - its absorbance at $470 \mathrm{~nm}$ was between 0.6 and 0.7 . In order to determine the antioxidant activity of the oil samples, $5 \mathrm{~mL}$ aliquots of the emulsion and $2 \mathrm{~mL}$ samples of oil diluted in ethanol $(3.5 \mathrm{mg} / 10 \mathrm{~mL})$ were mixed and kept in water bath at $50^{\circ} \mathrm{C}$. Butylated hydroxytoluene (BHT) was used as reference standard at the same concentration of the samples. Absorbance was read at $470 \mathrm{~nm}$ on a spectrophotometer (Spectronic ${ }^{\circledR}$ 20 Genesys, Spectronic Instruments Rochester, USA) every 15 minutes over a period of $120 \mathrm{~min}$.

(2) DPPH free radical scavenging assay - analysis was conducted as described in Brand-Williams et al. (1995) and Blois (1958), with some adjustments. This method is based on the decrease in absorbance of DPPH (2,2-diphenyl-1-picrylhydrazyl) when it is reduced by an antioxidant, a hydrogen donor. The amount of antioxidant needed to reduce DPPH concentration by $50 \%$ (IC50) is then calculated. Briefly, LO and PSO samples were diluted in n-butanol to different concentrations. A $0.5 \mathrm{~mL}$ aliquot at each concentration was then mixed with $1.5 \mathrm{~mL}$ of DPPH• in butanol $(3.0 \mathrm{mg} / 200 \mathrm{~mL})$ to initiate the reaction. After 30 minutes, absorbance was measured at $517 \mathrm{~nm}$ on a spectrophotometer (Spectronic ${ }^{\circledR} 20$ Genesys, Spectronic Instruments Rochester, USA). The DPPH solution (without sample) was used as control and BHT was used as standard. The DPPH scavenging activity of the sample was calculated according to Equation 1 and expressed as percentage.

Scavenging activity $(\%)=\left(\mathrm{Abs}_{\text {control }}-\mathrm{Abs}_{\text {sample }}\right) \div \mathrm{Abs}_{\text {control }}$

where $\mathrm{Abs}_{\text {control }}$ is the absorbance of the control and $\mathrm{Abs}_{\text {sample }}$ is the absorbance of the sample.
(3) Rancimat ${ }^{\circledR}$ assay - the test evaluates stability of oils and fats against autoxidation by exposing them to oxidizing conditions and measuring the time until volatile acids are detected (Rancimat induction time). The appearance of these acids is recorded in the measuring instrument as an increase in conductivity (Méndez et al., 1996). The equipment used was a Metrohm 743 Rancimat (Metrohm Instruments, Herisau, Switzerland) with software (1.0) control. Oil samples (5 g) were exposed to oxidation at $110^{\circ} \mathrm{C}$ (oxygen flow rate of $20 \mathrm{~L} / \mathrm{h}$ ). Induction times (IT) were recorded automatically and expressed in hours (h).

\section{Statistical analysis}

Data were expressed as mean \pm standard deviation $(n=3)$. Initially, the levels of fatty acids in both oils (LO and PSO), determined by two different esterification methods, were tested for homogeneity of variances using an F-test. Then, the Student's t-test (for independent samples) and the non-parametric Mann-Whitney U-test were used to test data for homogeneous and heterogeneous variances, respectively. The homogeneity of variances of data for quality and oxidative stability of oils was tested using the same tests described above.

The Hartley/Levene's test indicated that the variances of data for oxidative stability of the vegetable oils (LO and PSO) and of the synthetic antioxidant BHT were homogeneous. Statistically significant differences $(\mathrm{p}<0.05)$ were evaluated by univariate analysis of variance (ANOVA) and means were compared by Fisher's least significant difference test. All analyzes were performed using Statistica 7 (Statsoft, USA) and Action 2.4 (Estatcamp, Brazil) software.

\section{Results and discussion}

\subsection{Fatty acids profile in LO and PSO}

In analyzing conjugated fatty acids (CFAs), it is essential that the method chosen be capable of separating and quantifying these geometric and positional isomers, avoiding additional isomerization during any stage of derivatization (Christie et al., 2007). Converting fatty acids into volatile derivatives, mainly methyl esters, is the first step to analyze their profile by chromatography (De la Fuente et al., 2006). The methods of methylation using $\mathrm{KOH}$ or $\mathrm{NaOCH}_{3}$ in methanol, at room temperature, have been most reliably used for converting conjugated fatty acids into methyl esters because they do not cause isomerization. Acid-catalyzed methylation, using $\mathrm{BF}_{3}, \mathrm{HCl}$ or $\mathrm{H}_{2} \mathrm{SO}_{4}$, on the other hand, favors the isomerization of dienes and trienes (Sassano et al., 2009; Chen et al., 2007; De la Fuente et al., 2006). Kramer et al. (1997) advocates that, although esterification using $\mathrm{NaOCH}_{3}$ in methanol does not cause isomerization, it fails to methylate free fatty acids. They also observe that an acid/base-catalysed approach is more successful at esterifying all fatty acids and reducing isomerization. In this study, fatty acids in samples of both oils (LO and PSO) were thus esterified by both an acid/base-catalysed method and a base-catalysed method in order to determine the better methodology for the analysis of fatty acids in PSO. The chromatograms for a standard mix of C4-C24 
methyl esters analyzed under three different chromatographic conditions (CC), 1, 2 and 3, are shown in Figure 1.

The chromatographic run under CC 1, described in Kramer et al. (1997), was 80 minutes long and resulted in good separation of, mainly short chain fatty acids (detected in the first 30 minutes). The second set of conditions (CC 2), described in Cordain et al. (2002), also succeeded in separating short-chain fatty acids, but failed to separate all fatty acids in the standard as the run did not last as long ( 66 minutes). This shorter chromatographic run time led to poor separation of long chain fatty acids, such as CLnAs (punicic acid), which are found chiefly in PSO. The analysis under the third set of conditions (CC3), described in Baublits et al. (2007), took the longest time (93 minutes) and successfully separated all the fatty acids; peaks of long chain fatty acids were clearly identified. These conditions, therefore, proved to be the most suitable for the analysis of PSO. Baublits et al. (2007) and Pinheiro (2010), who applied these chromatographic conditions to determine the fatty acid profile of meat and milk of ruminants, containing conjugated linoleic acids, reported well-separated peaks of fatty acids. Also, Pinheiro (2010) observed that this set of chromatographic conditions, compared with the other two (described in Cordain et al., 2002 and Kramer et al., 1997), is the most appropriate because it provides satisfactory separation of the isomers of oleic and linoleic acids.
The fatty acid profiles for $\mathrm{LO}$ and PSO, determined by two different methods of esterification (acid/base-catalysed and base-catalysed) under chromatographic conditions (CC3), described in Baublits et al. (2007), are shown in Table 1. Good separation of fatty acids in the samples was obtained by using both methods. Esterification with $\mathrm{NaOCH}_{3}$ showed a chromatogram with fewer peaks probably because it more efficiently methylated the fatty acids, without the occurrence of isomerization. This is in agreement with observations made by Sassano et al. (2009), Chen et al. (2007) and De la Fuente et al. (2006), who have successfully methylated fatty acids with $\mathrm{NaOCH}_{3}$ or $\mathrm{KOH}$ in methanol. They also recommend it as the most reliable method as it does not cause isomerization and reduces the loss of short-chain fatty acids.

Table 1 confirms that the major fatty acids in PSO and $\mathrm{LO}$ are punicic acid (PA; C18:3-9c, 11t, 13c) and $\alpha$-linolenic acid (LNA; C18:3 $\omega-3$ ), respectively. The results for $L O$ are in agreement with the literature, which reports LNA percentages in LO ranging from about 50 to 58\% (Akpolat et al., 2011; Rosa et al., 2010; Tzang et al., 2009; Cintra et al., 2006). Five fatty acids, C16:0 (6.45\%), C18:0 (4.35\%), C18: $1 \omega-9$ (18\%), C18:2 $\omega-6(12.71 \%)$ and C18:3 $\omega-3$ (58.47\%), have been dentified in LO (Rosa et al., 2010). Literature on PSO reports variation in fatty acid composition; for instance, PA levels
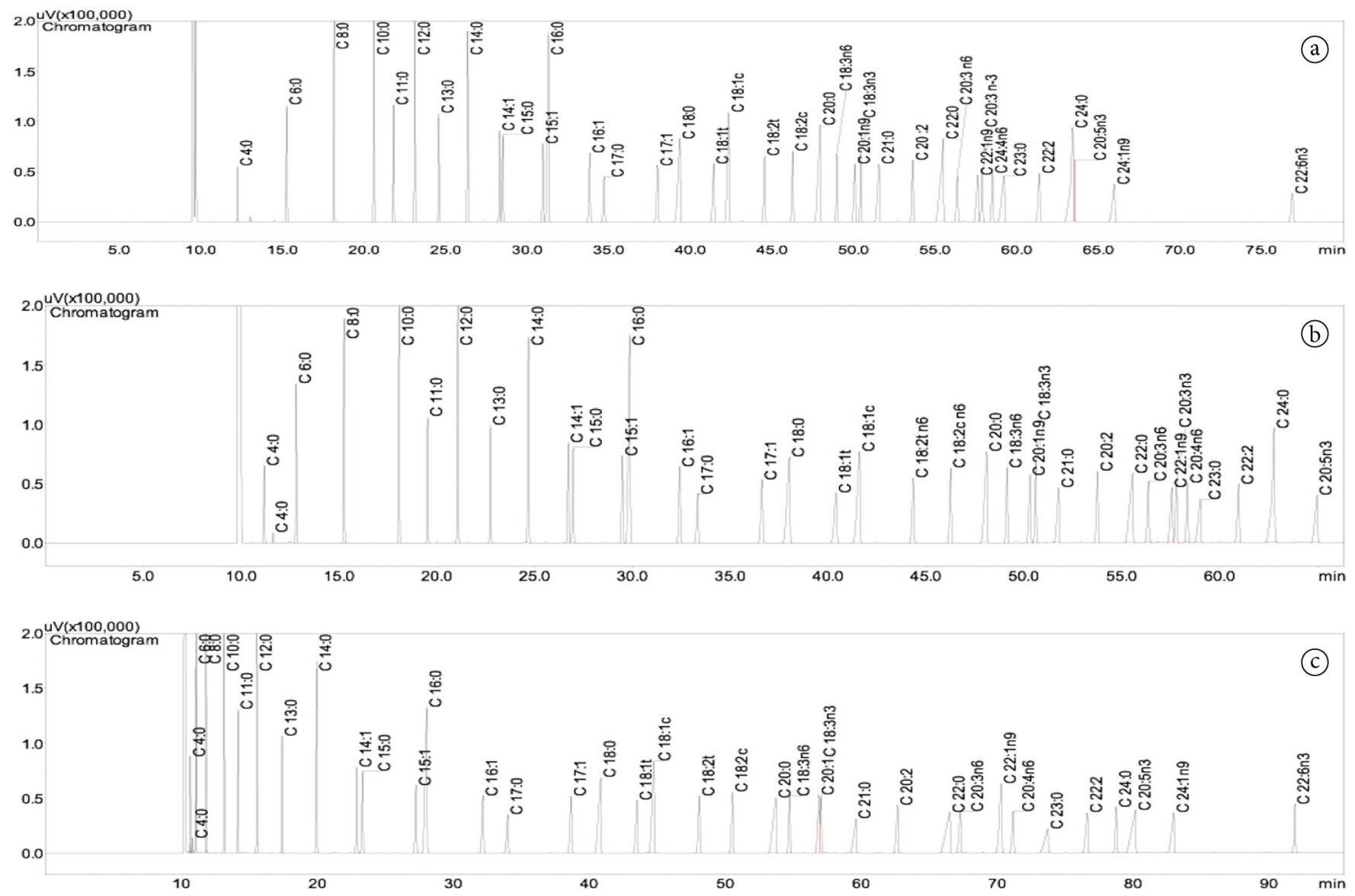

Figure 1. Chromatograms for a standard mix of C4-C24 methyl esters tested under three different chromatographic conditions (CC): (a) 1, (b) 2 and (c) 3 . 
fall between $37 \%$ and $81 \%$. Low levels of other conjugated triene fatty acids in PSO have also been reported, which is consistent with the observations in this study (Elfalleh et al., 2011; Parashar et al., 2010; Kýralan et al., 2009; Pande \& Akoh, 2009; Jardini \& Mancini-Filho, 2007). The acid-base system, however, catalyzed the conversion of punicic acid into other cis/trans CLnAs in PSO, causing a reduction in punicic acid levels, from $54.9 \%$ to $42.3 \%$, and an increase of all other isomers as well as the formation of two unidentified isomers. Similarly, Sassano et al. (2009) observed a drop in PA levels (from 71.8\% to $64.9 \%$ ) when fatty acids in PSO were methylated using both an acid- and a base-catalysed methods. They also reported a concomitant rise in the percentages of $\alpha$ - and $\beta$-eleostearic acids and catalpic acid.

\subsection{Content of tocopherols and phytosterols in PSO and LO}

The amounts of relevant compounds such as tocopherols in seed oils are often correlated to the relatively abundant levels of unsaturated fatty acids, which represents a further advantage in terms of nutraceutical value (Caligiani et al., 2010). As both linseed oil (LO) and pomegranate seed oil (PSO) are rich in unsaturated fatty acids, their content of tocopherols was analyzed (Table 2).

Total tocopherol levels were about three times as high in PSO than in LO (Table 2). However, higher values ( $300 \mathrm{mg} / 100 \mathrm{~g})$ of vitamin $\mathrm{E}$ in $\mathrm{PSO}$ have been reported; $\boldsymbol{\alpha}$-tocopherol, found to be in low amounts in the present study, and the $\gamma$-tocopherol was the predominant isomer (Elfalleh et al., 2011; Caligiani et al., 2010). Elfalleh et al. (2011) noted that tocopherols in seed oil from the Tunisian pomegranate consisted chiefly of $\alpha$-tocopherol (over 53\%). They also observed that the high levels of tocopherols in the oil were highly correlated with FRAP (ferric reducing antioxidant power) and ORAC (oxygen radical absorbance capacity) values, suggesting the contribution of tocopherols to the antioxidant properties of the oil. Phytosterols are found at different levels in all vegetable oils and account for the largest group of compounds in their unsaponifiable fraction (Mancini-Filho et al., 2007). The levels of phytosterols in LO and PSO are shown in Table 2.

The most abundant phytosterol in both oils was $\beta$-sitosterol. Also, the total content of phytosterols was greater in PSO than

Table 1. Fatty acids profile (\%) in linseed oil (LO) and pomegranate seed oil (PSO) determined using two methods of esterification (acid/base-catalysed and base-catalysed).

\begin{tabular}{|c|c|c|c|c|c|c|}
\hline \multirow{2}{*}{ Fatty acids } & \multicolumn{3}{|c|}{ LO } & \multicolumn{3}{|c|}{ PSO } \\
\hline & Acid/Base & Base & P-value & Acid/Base & Base & P-value \\
\hline C16:0 & $6.03 \pm 0.02$ & $6.06 \pm 0.01$ & 0.10 & $2.95 \pm 0.01$ & $2.77 \pm 0.00$ & $<0.01$ \\
\hline C18:0 & $5.22 \pm 0.02$ & $5.27 \pm 0.00$ & 0.01 & $2.57 \pm 0.01$ & $2.42 \pm 0.00$ & $<0.01$ \\
\hline C18:1cw-9 & $21.61 \pm 0.03$ & $21.73 \pm 0.00$ & $<0.01$ & $6.07 \pm 0.02$ & $5.74 \pm 0.01$ & $<0.01$ \\
\hline C18:1c $\omega-7$ & $0.72 \pm 0.00$ & - & NA & $0.34 \pm 0.00$ & - & $\mathrm{NA}$ \\
\hline $\mathrm{C} 18: 2 c \omega-6$ & $14.58 \pm 0.00$ & $14.67 \pm 0.00$ & $<0.01$ & $7.73 \pm 0.03$ & $7.29 \pm 0.01$ & $<0.01$ \\
\hline C20:0 & - & - & & $0.72 \pm 0.00$ & $0.39 \pm 0.00$ & $<0.01$ \\
\hline C20:1c $\omega-9$ & - & - & & $0.42 \pm 0.00$ & $0.39 \pm 0.00$ & $<0.01$ \\
\hline $\mathrm{C} 18: 3 c \omega-3$ & $51.85 \pm 0.08$ & $52.37 \pm 0.01$ & $<0.01$ & $0.43 \pm 0.00$ & $0.39 \pm 0.00$ & $<0.01$ \\
\hline C21:0 & - & - & & $0.41 \pm 0.00$ & $2.91 \pm 0.00$ & $<0.01$ \\
\hline $\mathrm{C} 18: 39 c 11 t 13 c$ & - & - & & $42.34 \pm 0.67$ & $54.90 \pm 0.03$ & $<0.01$ \\
\hline NI & - & - & & $6.22 \pm 0.05$ & - & NA \\
\hline NI & - & - & & $1.99 \pm 0.05$ & - & NA \\
\hline C18:3 $9 c 11 t 13 t$ & - & - & & $17.29 \pm 0.16$ & $16.07 \pm 0.01$ & $<0.01$ \\
\hline C18:3 $9 t 11 t 13 c$ & - & - & & $10.19 \pm 0.43$ & $6.71 \pm 0.00$ & $<0.01$ \\
\hline C18:3 9t11t13t & - & - & & $0.33 \pm 0.00$ & - & NA \\
\hline
\end{tabular}

Chromatographic conditions (CC3) - Baublits et al. (2007); NI = not identified; NA = Not applicable; Results are expressed as mean \pm standard deviation ( $\mathrm{n}=3$ ); P-value (paired Student's t test).

Table 2. Content of tocopherols and phytosterols in linseed (LO) and pomegranate seed (PSO) oils.

\begin{tabular}{|c|c|c|c|c|c|}
\hline \multicolumn{6}{|c|}{ Tocopherols (mg/100g) } \\
\hline Samples & a-tocopherol & $\beta$-tocopherol & $\gamma$-tocopherol & $\delta$-tocopherol & Total \\
\hline LO & $0.93 \pm 0.01^{b}$ & $18.17 \pm 1.90^{\mathrm{a}}$ & $32.96 \pm 3.37^{b}$ & $1.39 \pm 0.01^{b}$ & $53.44 \pm 5.26^{b}$ \\
\hline PSO & $3.81 \pm 0.08^{\mathrm{a}}$ & $1.03 \pm 0.01^{\mathrm{b}}$ & $153.21 \pm 2.44^{\mathrm{a}}$ & $17.04 \pm 1.65^{\mathrm{a}}$ & $175.09 \pm 3.50^{\mathrm{a}}$ \\
\hline P-value & $<0.01$ & $<0.01$ & $<0.01$ & $<0.01$ & $<0.01$ \\
\hline \multicolumn{6}{|c|}{ Phytosterols (mg/100g) } \\
\hline Samples & Campesterol & $\beta$-sitosterol & Stigmasterol & others & Total \\
\hline LO & $66 \pm 2.4^{b}$ & $138 \pm 4.0^{\mathrm{a}}$ & $11 \pm 0.5^{b}$ & $113 \pm 3.7^{b}$ & $328 \pm 11^{b}$ \\
\hline PSO & $49 \pm 1.6$ & $374 \pm 1.4$ & $12 \pm 0.7^{\mathrm{a}}$ & $104 \pm 7.4^{\mathrm{a}}$ & $539 \pm 11^{\mathrm{a}}$ \\
\hline P-value & $<0.01$ & $<0.01$ & 0.05 & 0.01 & $<0.01$ \\
\hline
\end{tabular}

Mean \pm standard deviation $(n=3)$; different letters in the same column are statistically different from each other, P-value (paired Student's t test). 
in LO, and is consistent with that observed in the literature (Caligiani et al., 2010; Pande \& Akoh, 2009).

\subsection{Quality parameters of $\mathrm{LO}$ and PSO}

In analyzing oils and fats, indices that characterize their physical and chemical properties are better indicators of quality than percentages of their components. These indices, along with some characteristic reactions, are used to identify and evaluate most oils and fats and the results of the analysis are based on this set of data (Instituto Adolfo Lutz, 2005). Table 3 shows the values of some quality and stability indices for LO and PSO samples.

The Codex Alimentarius (2009) (CODEX-STAN, 210-1999) recommends that the acidity and peroxide indices of cold pressed oils should not exceed $4.0 \mathrm{mg} / \mathrm{g}$ and $15 \mathrm{meq} / \mathrm{kg}$, respectively. Overall, the indices for LO and PSO met the standards of quality and showed good stability of both oils.

\subsection{Oxidative stability of $L O$ and PSO}

The rate of reduction in absorbance of $\beta$-carotene in the presence of the oils studied (LO and PSO) and the synthetic antioxidant BHT (0.01\%) is shown in Figure 2a. The percentage inhibition of the oxidation of $\beta$-carotene by both oils and BHT is shown in Figure $2 \mathrm{~b}$. The antioxidant BHT was the most stable, followed by PSO (21\%) and LO (4\%). Using the same methodology, Schubert et al. (1999) reported a higher percentage (approximately 40\%) for cold pressed PSO, close to that observed for green tea. They attributed its high antioxidant activity to both fatty acid composition and the presence of flavonoids.

The DPPH scavenging capacity of LO and PSO versus their concentration and the percentage of DPPH reduced by both oils and BHT at $1 \mathrm{mg}$ are shown in Figures 3a, b, respectively. Pomegranate seed oil (PSO) showed greater concentration-dependent scavenging capacity than $\mathrm{LO}$ (Figure $3 \mathrm{a}$ ), but significantly lower activity compared to the synthetic antioxidant BHT $(1 \mathrm{mg})$ (Figure $3 \mathrm{~b}$ ). While the amount of PSO needed to reduce DPPH concentration by $50 \%$ (EC50) was 3.77, the amount of BHT was a mere $0.26 \mathrm{mg}$; the lower the EC50, the more potent $\mathrm{DPPH}$ • scavenger the antioxidant is (Ali et al., 2012). Linseed oil (LO) was incapable of reducing DPPH $\bullet$ radicals at $1 \mathrm{mg}$ (Figure $3 \mathrm{~b}$ ).

Conjugated fatty acids have been reported as potent antioxidants in animal organisms. However, the in vitro antioxidant activities of CLnAs and of the oils rich in them have been scarcely investigated. The DPPH• scavenging capacity results for PSO in this work mirror previous findings from studies using conjugated linoleic acid (CLA) (Ali et al., 2012; Fagali \& Catalá, 2008; Yu, 2001). Isomers of CLAs have been shown to have a considerable direct antioxidant capacity and significant $\mathrm{DPPH}$ • scavenging properties at different concentrations although they were less effective than vitamin E and BHT (Ali et al., 2012). CLAs provide protection against free radicals, but linoleic acid, one of their non-conjugated isomers, does not (Fagali \& Catalá, 2008; Yu, 2001).

Unlike the $\beta$-carotene oxidation and DPPH• scanvenging results, which were significantly different for LO and PSO, Rancimat ${ }^{\circledR}$ induction times for both oils were similar $(0.72 \pm 0.03$ and $0.73 \pm 0.07$ hours, respectively). Free radicals attack unsaturated fatty acid chains at the methylene group between two double bonds, removing a hydrogen atom and producing other free radicals (Mancini \& Mancini-Filho, 2005). However, no differences in oxidative stability between the oils studied, rich in conjugated and unconjugated fatty acids, were shown by the Rancimat ${ }^{\circledR}$ assay. The $\beta$-carotene/linoleic acid and DPPH•

Table 3. Quality and stability parameters for linseed (OL) and pomegranate seed (PSO) oils.

\begin{tabular}{ccccc}
\hline Samples & AI $(\mathbf{m g} / \mathbf{g})$ & PI $(\mathbf{m E g} / \mathbf{k g})$ & IpA & TBA $(\mu \mathrm{g} / \mathbf{g})$ \\
\hline LO & $1.04 \pm 0.00^{\mathrm{a}}$ & $4.40 \pm 0.02^{\mathrm{a}}$ & $0.56 \pm 0.33^{\mathrm{b}}$ & $0.44 \pm 0.01^{\mathrm{a}}$ \\
PSO & $0.63 \pm 0.00^{\mathrm{b}}$ & $3.34 \pm 0.03^{\mathrm{b}}$ & $4.84 \pm 1.01^{\mathrm{a}}$ & $0.22 \pm 0.01^{\mathrm{b}}$ \\
P-value & $<0.01$ & $<0.01$ & 0.01 & $<0.01$ \\
\hline
\end{tabular}

$\mathrm{AI}$ (acidity index); PI (peroxide index); IpA (p-anisidine index); TBA (2-thiobarbituric acid value); mean \pm standard deviation $(\mathrm{n}=3)$; different letters in the same column are statistically different from each other, P-value (paired Student's test).
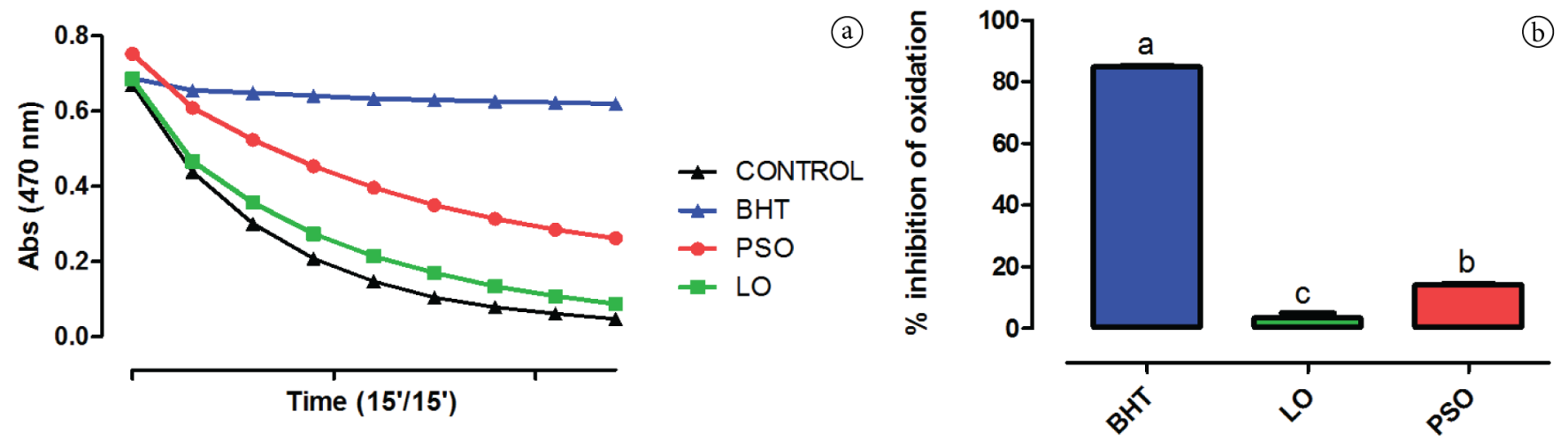

Figure 2. (a) Kinetics of the inhibition of oxidation of $\beta$-carotene by linseed oil (LO), pomegranate seed oil (PSO) and BHT (0.01\%) and (b) percentage inhibition by LO, PSO and BHT; One Way ANOVA $(\mathrm{p}<0.01)$. 

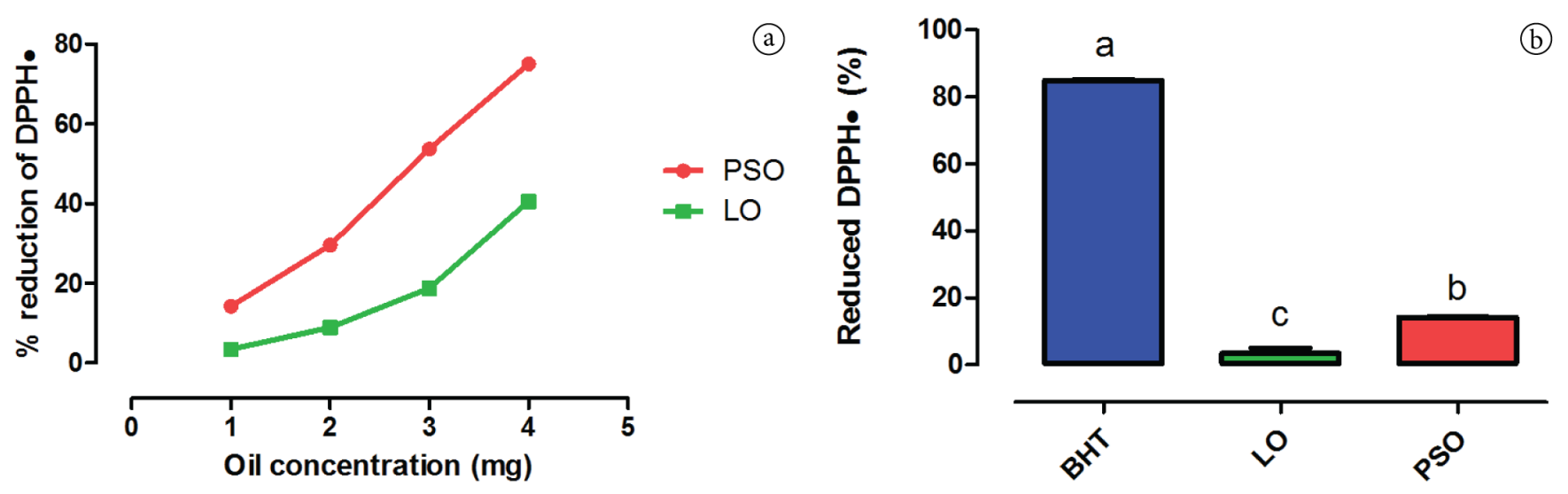

Figure 3. (a) DPPH• scavenging capacity of linseed (LO) and pomegranate seed (PSO) oils (b) (\%) DPPH• reduced by both oils and BHT at $1 \mathrm{mg}$. One Way ANOVA $(\mathrm{p}<0.01)$.

tests, on the other hand, yielded greater oxidative stability results for PSO than for LO. Yang et al. (2009) compared the oxidative stability of individual CLnA isomers and of LNA, its corresponding non-conjugated acid, by oxidizing both in air at $50^{\circ} \mathrm{C}$ and monitoring reactions by gas chromatography and the oxygen consumption test, and observed that CLnAs were more susceptible to autoxidation than LNA. Of the three groups of isomers of CLnAs, isomers $t, t, t$-CLnA showed the greatest stability, followed by $c, t, t$-CLnA and $c, t, c$-CLnA. Stability of CLnA geometric isomers in each group was also found to be dependent on the position of the three conjugated double bonds. The presence of CLnAs can contribute to oxidative deterioration of vegetable oils (Kinami et al., 2007). However, PSO met all standards of quality, and most of the indices evaluated were below those of soybean oil, rich in unconjugated fatty acids, reported by Kinami et al. (2007).

\section{Conclusions}

The base-catalised esterification method under chromatographic conditions described in Baublits et al. (2007) was found to be the most appropriate methodologe to analyse pomegranate seed oil samples by gas chromatography.

The results in this study confirm the presence of high concentrations of conjugated $\alpha$-linolenic acid, vitamin $\mathrm{E}$ and phytosterols in pomegranate seed oil and show that the oil has good oxidative stabilitly despite the high degree of unsaturation of its fatty acids. Further studies are needed to confirm the effects of pomegranate seed oil in different systems and under physiological conditions.

\section{Acknowledgements}

The authors would like to thank the São Paulo State Research Foundation (FAPESP) for funding the research and for granting a scholarship (FAPESP Process 09/51891-7; 09/51890-0 and 13/24490-7). We also acknowledge the funding provided by the National Council for Technological and Scientific Development (CNPq).

Neither of the authors has conflicts of interest to disclose.

\section{References}

Akpolat, M., Kanter, M., Topcu-Tarladacalisir, Y., \& Aydogdu, N. (2011). Protective effect of flaxseed oil on renal injury in hyperlipidaemic rats: the effect of flaxseed oil on hyperlipidaemia. Phytotherapy Research : PTR, 25(6), 796-802. http://dx.doi.org/10.1002/ptr.3334. PMid:21077265.

Ali, Y. M., Kadir, A. A., Ahmad, Z., Yaakub, H., Zakaria, Z. A., \& Abdullah, M. N. H. (2012). Free radical scavenging activity of conjugated linoleic acid as single or mixed isomers. Pharmaceutical Biology, 50(6), 712-719. http://dx.doi.org/10.3109/13880209.2011. 621714. PMid:22181061.

Almeida, C. A. S. (2009). Avaliação dos principais fitosteróis em óleos vegetais e azeite (Master's dissertation). Faculdade de Engenharia de Alimentos, Universidade Estadual de Campinas, Campinas.

American Oil Chemists' Society - AOCS. (2004). Official methods and recommended practices of the American Oil Chemists' Society. Champaign: AOCS.

Baublits, R. T., Pohlman, F. W., Brown, A. H. Jr, Johnson, Z. B., Proctor, A., Sawyer, J., Dias-Morse, P., \& Galloway, D. L. (2007). Injection of conjugated linoleic acid into beef strip loins. Meat Science, 75(1), 8493. http://dx.doi.org/10.1016/j.meatsci.2006.07.006. PMid:22063415.

Blois, M. S. (1958). Antioxidant determinations by the use of a stable free radical. Nature, 181(4617), 1199-1200. http://dx.doi. org/10.1038/1811199a0.

Brand-Williams, W., Cuvelier, M. E., \& Berset, C. (1995). Use of a free radical method to evaluate antioxidant activity. $L W T$ - Food Science and Technology (Campinas.), 28(1), 25-30. http://dx.doi.org/10.1016/ S0023-6438(95)80008-5.

Caligiani, A., Bonzanini, F., Palla, G., Cirlini, M., \& Bruni, R. (2010). Characterization of a potential nutraceutical ingredient: pomegranate (Punica granatum L.) seed oil unsaponifiable fraction. Plant Foods for Human Nutrition (Dordrecht, Netherlands), 65(3), 277-283. http:// dx.doi.org/10.1007/s11130-010-0173-5. PMid:20607413.

Chen, J., Cao, Y., Gao, H., Yang, L., \& Chen, Z.-Y. (2007). Isomerization of conjugated linolenic acids during methylation. Chemistry and Physics of Lipids, 150(2), 136-142. http://dx.doi.org/10.1016/j. chemphyslip.2007.06.223. PMid:17681289.

Christie, W. W., Dobson, G., \& Adlof, R. O. (2007). A practical guide to the isolation, analysis and identification of conjugated linoleic 
acid. Lipids, 42(12), 1073-1084. http://dx.doi.org/10.1007/s11745007-3107-8. PMid:17710464.

Christie, W. W., Sébédio, J. L., \& Juanéda, P. (2001). A practical guide to the analysis of conjugated linoleic acid (CLA). Inform (Silver Spring, Md.), 152, 147-152.

Cintra, D. E. C., Costa, A. V., Peluzio, M. D. C. G., Matta, S. L. P., Silva, M. T. C., \& Costa, N. M. B. (2006). Lipid profile of rats fed high-fat diets based on flaxseed, peanut, trout, or chicken skin. Nutrition (Burbank, Los Angeles County, Calif.), 22(2), 197-205. http://dx.doi. org/10.1016/j.nut.2005.09.003. PMid:16459232.

Codex Alimentarius. (2009). Codex standard for named vegetable oils codex stan 210-1999. Codex Alimentarius. Retrieved from: http:// www.codexalimentarius.org

Cordain, L., Watkins, B. A., Florant, G. L., Kelher, M., Rogers, L., \& Li, Y. (2002). Fatty acid analysis of wild ruminant tissues: evolutionary implications for reducing diet-related chronic disease. European Journal of Clinical Nutrition, 56(3), 181-191. http://dx.doi.org/10.1038/ sj.ejcn.1601307. PMid:11960292.

De la Fuente, M. A., Luna, P., \& Juárez, M. (2006). Chromatographic techniques to determine conjugated linoleic acid isomers. TrAC Trends in Analytical Chemistry, 25(9), 917-926. http://dx.doi. org/10.1016/j.trac.2006.04.012.

Elfalleh, W., Ying, M., Nasri, N., Sheng-Hua, H., Guasmi, F., \& Ferchichi, A. (2011). Fatty acids from Tunisian and Chinese pomegranate (Punica granatum L.) seeds. International Journal of Food Sciences and Nutrition, 62(3), 200-206. http://dx.doi.org/10.3109/0963748 6.2010.526932. PMid:21118055.

Fagali, N., \& Catalá, A. (2008). Antioxidant activity of conjugated linoleic acid isomers, linoleic acid and its methyl ester determined by photoemission and DPPH techniques. Biophysical Chemistry, 137(1), 56-62. http://dx.doi.org/10.1016/j.bpc.2008.07.001. PMid:18656302.

Instituto Adolfo Lutz - IAL. (2005). Métodos Físico-Químicos para Análise de Alimentos (4th ed., Série A. Normas e Manuais Técnicos). São Paulo: IAL. 1018 p.

Jardini, F. A., \& Mancini, J. Fo. (2007). Composição centesimal e perfil dos ácidos graxos da romã (Punica granatum, L.) cultivada no Brasil. Higiene Alimentar, 21(148), 81-85.

Johanningsmeier, S. D., \& Harris, G. K. (2011). Pomegranate as a functional food and nutraceutical source. Annual Review of Food Science and Technology, 2(1), 181-201. http://dx.doi.org/10.1146/ annurev-food-030810-153709. PMid:22129380.

Kinami, T., Horii, N., Narayan, B., Arato, S., Hosokawa, M., Miyashita, K., Negishi, H., Ikuina, J., Noda, R., \& Shirasawa, S. (2007). Occurrence of conjugated linolenic acids in purified soybean oil. Journal of the American Oil Chemists' Society, 84(1), 23-29. http:// dx.doi.org/10.1007/s11746-006-1005-5.

Kramer, J. K. G., Fellner, V., Dugan, M. E. R., Sauer, F. D., Mossoba, M. M., \& Yurawecz, M. P. (1997). Evaluating acid and base catalysts in the methylation of milk and rumen fatty acids with special emphasis on conjugated dienes and total trans fatty acids. Lipids, 32(11), 12191228. http://dx.doi.org/10.1007/s11745-997-0156-3. PMid:9397408.

Kýralan, M., Gölükcü, M., \& Tokgöz, H. (2009). Oil and conjugated linolenic acid contents of seeds from important pomegranate cultivars (Punica granatum L.) grown in Turkey. Journal of the American Oil Chemists' Society, 86(10), 985-990. http://dx.doi.org/10.1007/ s11746-009-1436-x.

Mancini, D. A. P., \& Mancini-Filho, J. (2005). Prevenção de reações oxidativas: antioxidantes nos vegetais de consumo humano. In R. C. De Angelis, A importância dos alimentos vegetais na proteção da saúde humana (cap. 36, pp. 206-214) São Paulo: Athene.
Mancini-Filho, J., Takemoto, E., \& Aued-Pimentel, S. (2007). Parâmetros de identidade e qualidade de óleos e gorduras. In L. B. AlmeidaMuradian \& M. D. V. C. Penteado, Vigilância Sanitária: tópicos sobre legislação de alimentos (cap. 6, p. 81-107). Rio de Janeiro: Guanabara Koogan.

Méndez, E., Sanhueza, J., Speisky, H., \& Valenzuela, A. (1996). Validation of the rancimat test for the assessment of the relative stability of fish oils. Journal of the American Oil Chemists' Society, 73(8), 1033-1037. http://dx.doi.org/10.1007/BF02523412.

Pande, G., \& Akoh, C. C. (2009). Antioxidant capacity and lipid characterization of six Georgia-grown pomegranate cultivars. Journal of Agricultural and Food Chemistry, 57(20), 9427-9436. http://dx.doi. org/10.1021/jf901880p. PMid:19743855.

Parashar, A., Sinha, N., \& Singh, P. (2010). Lipid contents and fatty acids composition of seed oil from twenty five pomegranates varieties grown in India. Advance Journal of Food Science, 2(1), 12-15. Retrieved from http://www.airitilibrary.com/Publication/alDetailedMesh?d ocid=20424876-201001-201009060052-201009060052-12-15

Pinheiro, F. G. (2010). Ácido linoleico conjugado em cortes bovinos e laticínios: avaliação de metodologias analíticas para a quantificação dos isômeros conjugados majoritários (Master's dissertation). Universidade de São Paulo, São Paulo.

Rosa, D. D., Sales, R. L., Moraes, L. F. S., Lourenço, F. C., Neves, C. A., Sabarense, C. M., Ribeiro, S. M. R., \& Peluzio, M. C. G. (2010). Flaxseed, olive and fish oil influence plasmatic lipids, lymphocyte migration and morphometry of the intestinal of Wistar rats. Acta Cirurgica Brasileira, 25(3), 275-280. http://dx.doi.org/10.1590/ S0102-86502010000300010. PMid:20498941.

Sassano, G., Sanderson, P., Franx, J., Groot, P., van Straalen, J., \& Bassaganya-Riera, J. (2009). Analysis of pomegranate seed oil for the presence of jacaric acid. Journal of the Science of Food and Agriculture, 89(6), 1046-1052. http://dx.doi.org/10.1002/jsfa.3552.

Schubert, S. Y., Lansky, E. P., \& Neeman, I. (1999). Antioxidant and eicosanoid enzyme inhibition properties of pomegranate seed oil and fermented juice flavonoids. Journal of Ethnopharmacology, 66(1), 11-17. http://dx.doi.org/10.1016/S0378-8741(98)00222-0. PMid:10432202.

Tsuzuki, T., Igarashi, M., Iwata, T., Yamauchi-Sato, Y., Yamamoto, T., Ogita, K., Suzuki, T., \& Miyazawa, T. (2004). Oxidation rate of conjugated linoleic acid and conjugated linolenic acid is slowed by triacylglycerol esterification and a-tocopherol. Lipids, 39(5), 475480. http://dx.doi.org/10.1007/s11745-004-1253-z. PMid:15506243.

Tzang, B.-S., Yang, S.-F., Fu, S.-G., Yang, H.-C., Sun, H.-L., \& Chen, Y.C. (2009). Effects of dietary flaxseed oil on cholesterol metabolism of hamsters. Food Chemistry, 114(4), 1450-1455. http://dx.doi. org/10.1016/j.foodchem.2008.11.030.

Yang, L., Cao, Y., Chen, J.-N., \& Chen, Z.-Y. (2009). Oxidative stability of conjugated linolenic acids. Journal of Agricultural and Food Chemistry, 57(10), 4212-4217. http://dx.doi.org/10.1021/jf900657f. PMid:19368396.

Yu, L. (2001). Free radical scavenging properties of conjugated linoleic acids. Journal of Agricultural and Food Chemistry, 49(7), 3452-3456. http://dx.doi.org/10.1021/jf010172v. PMid:11453790.

Zock, P. L. (2006). Health problems associated with saturated and trans fatty acids intake. In C. Williams, J. Buttriss, Improving the fat content of foods (cap. 1, part 1). Boca Raton: CRC Press. 